\title{
DETERMINANTS OF EFFECTIVE PRODUCT PLACEMENT IN COMPUTER GAMES - LITERATURE REVIEW
}

\author{
Magdalena Hofman-Kohlmeyer ${ }^{1}$
}

\begin{abstract}
Product placement is a common tool in promotional campaign. Marketers feature products in the plot of movies or TV programs to improve brand image and influence purchase decisions. Companies more often decide to embed products or brand identifiers inside computer games. Product placement attracts attention of managers as well as scholars. Vast parts of research focused on determinants of effective product placement in a game environment. The present paper aims to represent the main determinants that influence the effectiveness of product placement and is based on literature review.
\end{abstract}

INTRODUCTION: Recently, we have witnessed the evolution of product placement in computer games. This new medium attracted many well-known companies such as IBM, Adidas or Coca-Cola. According to the growing popularity of placing product in games, an increase in scientists' interest in the effectiveness of this phenomenon can be observed. Research focuses on evaluating players' brand memory, attitudes toward to the game, product or brand, and purchasing intentions. It is important to note that brands placed in games affect the audience in different degrees because the brand can be featured in various ways. Some of the scholars investigated the factors that can exert influence on the effectiveness of product placement in computer games.

OBJECTIVES: The present paper is aimed to investigate the main determinants of effective product placement in computer games.

METHODS: The article is based on polish and foreign literature review.

RESULTS: The growing ranks of scholars has been observed to have interest in the effectiveness of product placement in computer games. According to the literature, it can be said that an effectiveness of product (or brand) placement in a game environment is determined by: the degree of product/brand visibility in the game (prominence as well as proximity), gameproduct congruity, customer engagement in a game, persuasive knowledge, and strategy of product or brand integration with the game. There is also research that explores how these determinants influence product placement effectiveness in a game environment.

CONCLUSION: Despite the progress made, there are still important limitations of the conducted research, e.g. results can be moderate by various circumstances such as using fictitious or real brands. In addition, the same factor can have positive as well as negative effects. For instance, product placement proximity on the one hand enhances brand recall, but on the other can cause negative attitudes toward the brand. There are also determinants with limited research such as influence of product or brand integration with the game on product (or brand) effectiveness.

JEL Classification Numbers: M31; DOI: http://dx.doi.org/10.12955/cbup.v6.1153

Keywords: product placement, brand placement, computer games

\section{Introduction}

The importance of new media in the marketing activities of enterprises is now undeniable. Modern online stores are created, sales through auction portals have gained popularity, information about customers is obtained via the Internet and databases are formed (Mitręga \& Hofman-Kohlmeyer, 2017). Messages that have an attractive form and are distributed by the popular source are more noticeable and better remembered (Kotler 2005). The prevalence and ubiquity of traditional promotional instruments leads to a search for new forms of promotion. In recent years, the interest in promotion in the new medium of computer games has increased (Hofman-Kohlmeyer, 2017). It is important to note that the images of a computer player have changed alongside this. The average player is not a child or teenager addicted to games and alienated from society. Research conducted in Poland proved that active players can be found in every age group, regardless of gender (Mitręga, 2013). The rapid development of games has made the players an attractive segment of the market (Mitręga, 2012). Many well-known companies such as IBM, Reuters, Dell, Cisco, American Apparel, Adidas, Toyota, and Coca-Cola have placed products or brands in these game (endra Sharma, Baoku \& Lijuan, 2012). Players can interact with the product in the medium of the computer game. For example, the game Porsche Challenge provided gamers with the opportunity to drive digital representations of the real car (Mackay et al., 2009). Branded products are used to convey a sense of realism into some online environments where products are used by game characters (avatars) or integrated into the background of the game scene (Winkler \& Buckner, 2006).

According to the growing popularity of product placement in computer games, an increase in scientists' interest in the effectiveness of this phenomenon can be observed. Research focuses on evaluating

\footnotetext{
${ }^{1}$ University of Economics in Katowice, Faculty of Informatics and Communication, magda-hofman@o2.pl
} 
players' brand memory, attitudes toward to the game, product or brand, and purchasing intentions (Gangadharbatla, Bradley \& Wise, 2013). In addition, brands placed in games affect the audience in different degrees because the brand can be featured in various ways. Some scholars investigated the factors that can exert influence on the effectiveness of product placement in computer games. The factors determining the effectiveness of placement include, for instance, the level of brand prominence in the game and the product - the game congruence (Vashisht, \& Pillai, S., 2016). The present paper is aimed to represent main determinants of effective product placement in computer games and is based on polish and foreign literature.

The article is organized as follows. The first part pertains to new promotional tools - product placement in computer games. The second part focuses on gathered determinants that are most often mentioned in literature.

\section{Product placement in computer games}

Product placement stands on the border between advertising and public relations. It encompasses the commercial placement in a movie, a spectacle, an entertainment program or a computer game of a story, stage or information aimed at achieving the intended marketing goals. Śliwińska and Pacut (2011) mentioned the following types of product placement: generic placement, utility placement, brand placement, corporate placement, and organization placement. Generic placement takes place when the product category is placed, without any information about the brand or producer. Utility placement shows the ways how the product should be utilized. Brand placement is when the brand and/or product is featured. Corporate placement can be described by the company name or brand of product featured on billboards, neon signs or others advertising medium. Organization placement takes place when an organization or company is embedded in the plot (Hofman-Kohlmeyer, 2017).

Product placement of brands in computer games combines entertainment and marketing communication. Obtrusiveness of traditional advertisement contributes to the emergence of a new solution known as branded entertainment. The combination of an entertainment and marketing message makes the border between entertainment and advertising blurred. Branded entertainment includes all paid activities that influence the audience, which are aimed to achieve commercial benefits through non-commercial projects. It is interesting that the target audiences may be unaware that any commercial influence is being exerted on them, hence they will probably process the content of the marketing message differently (Martí-Parreño et al., 2013).

In computer games many examples of different types of product placement can be found. Companies can set up virtual stores in order to allow residents to use virtual products. For example, Toyota shows this in Second Life virtual editions of the Scion xB model (Kaplan \& Haenlein, 2009b) and similarly Renault in the The Sims game (Figure 1) (Mitręga, 2013).

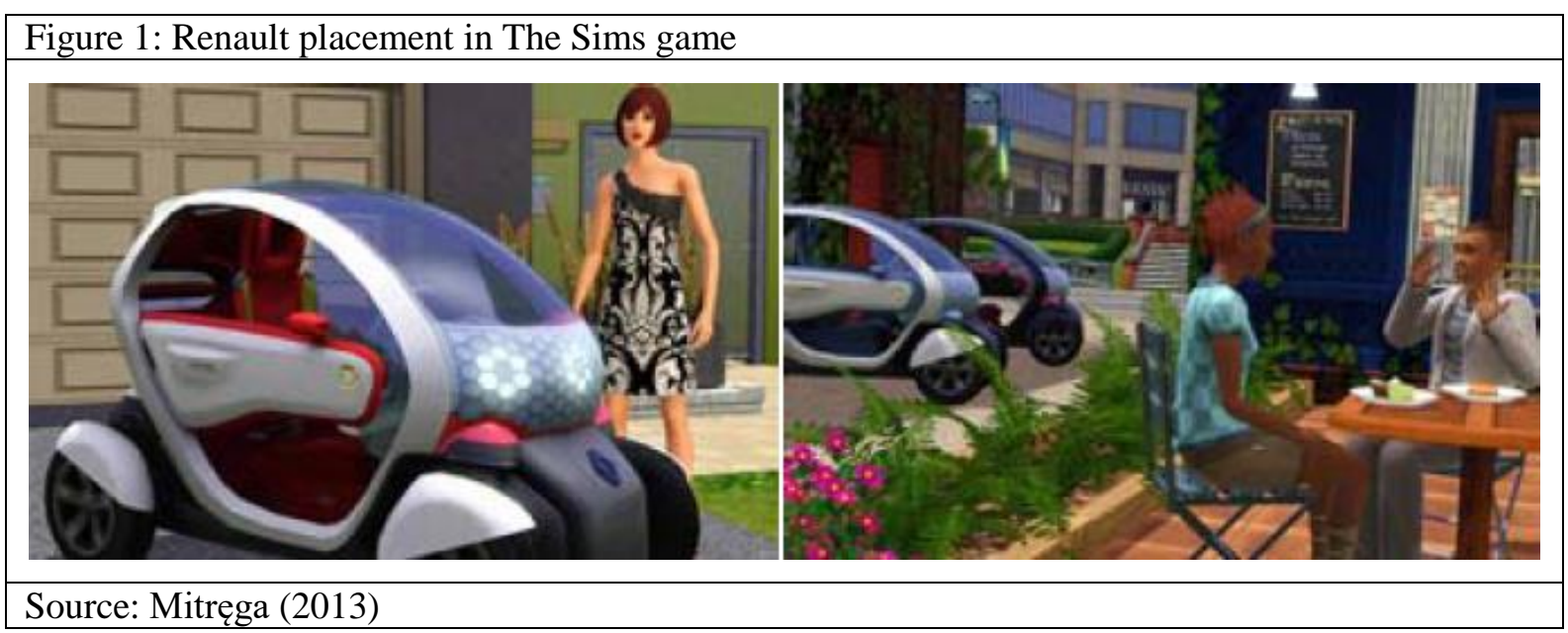

Firms expect that virtual stores in Second Life will help them to reach new customers and better understand their needs (Arakji \& Lang, 2008). The Crowne Plaza hotel chain, owned by the InterContinental Hotels Group, offers companies virtual meeting rooms in Second Life in the same way as they can rent rooms in Crowne Plaza hotels in the United States, Great Britain, or Switzerland (Kaplan \& Haenlein, 2009b). Some companies choose setting up virtual stores with full transactional 
opportunities, for example American Apparel sells virtual versions of their real products. Other companies decide to only allow residents to interact with the virtual products or services without buying anything. These companies are focused on building a brand image (Arakji \& Lang, 2008). Avatars buy various products and services for entertainment purposes. Moreover, products and brands help them to build their virtual identities (Koles \& Nagy, 2012). The large logistic company, Deutsche Post World Net, offered virtual cards to Second Life residents. Thereafter, these cards are subsequently delivered as real postcards all around the world. This specific form of selling can help overcome certain disadvantages associated with traditional electronic commerce, e.g. a lack of appropriate product presentation, and above all fashion and design items or insufficient social interaction (Kaplan \& $\mathrm{M}$. Haenlein, 2009b). Similar activities were also implemented by firms like Circuit City and Amazon and evoked positive reactions among Second Life users (Kaplan \& Haenlein, 2009a).

Marketers frequently use virtual mass media similarly like in the real world. They can choose advertisements in newspapers or on virtual radio, and pay for ads in location search engines. The most popular places for brand advertisements are billboards, banners, screens and neon lights on virtual buildings (Laskowska-Witek \& Mitręga, 2014). An example represents use by Canada's IMAX Corporation of virtual advertising to promote fifth part of the Harry Potter saga, namely "Harry Potter and the Order of the Phoenix" (Kaplan \& Haenlein, 2009b).

Companies often organize exhibitions, cultural and shopping events, lectures, as well as talks and competitions. For example, L'Oreal Paris and virtual modeling agency Aspire organized a contest for the face of "L'Oreal Paris Glamour Fashion Show". Similarly, Coca-Cola organized a competition where participants created a project of virtual machines for beverages (Laskowska-Witek \& Mitręga, 2014). IBM held virtual conferences in 2008 in order to increase its presence in the market for technologies. They reduced the real-world cost and were able to reach people all around the world. In the same year, Intel also conducted virtual conferences. The event included keynote presentations, live product demos and social networking activities. These conferences were fun for participants and created shared memories. In addition, participants can use text chat for conversations during the event (endra Sharma, Baoku \& Juan, 2011).

Very often, well-known companies decide to buy their own locations inside the virtual world such as the Second Life game. These locations are named "branded islands" and are places where residents of Second Life can relax, play, purchase virtual products, as well as are strongly associated with the brand community (Laskowska-Witek \& Mitręga, 2014). In 2006, Coca-Cola bought its own island to promote the brand and gather the public community. Residents can visit "Coke Studio" to record music and get free virtual drinks. The advantages for Coca-Cola are brand promotion, marketing campaigns, public attention and business strategy (endra Sharma, Baoku \& Juan, 2011).

\section{Determinants of effective product placement}

The factors determining the effectiveness of placement include the degree of brand visibility in the game. In literature, brand visibility is described as a brand (or product) proximity and prominence. According to Lee and Faber (2007) product placement proximity is related to location of the logotype of the brand in the game. Certain brands are located in the central point, where the action of the game is played (focal placement), while others are placed in the background (peripheral placement) (Lee \& Faber, 2007). However, according to Gupta and Lord prominent placement is defined as placement characterized by a high degree of visibility through the size or position on the screen or place in the central action point. As the opposite, the authors suggest subtle placement, characterized by small size, location away from the place of the game action or short display time (Gupta \& Lord, 1998; Cauberghe \& Pelsmacker, 2010).

Some advertisers embed brands in games that match the product such as Dodge, which featured its vehicles in a car-based game, while others choose games that are not related to the type of located product. In literature, this relationship is called game-product congruity. It is assumed that this relationship may affect the customers' brand recall (Lee \& Faber, 2007).

Lee and Faber (2007) carried out a research on a group of 155 students, in which $98 \%$ of them were between 18 and 25 years of age and $67 \%$ were women. Participants played a game based on car racing. The game was adjusted to the needs of the experiment. The game includes brands that are divided into the following categories: petrol, deodorants, and animal feed. The brand name and image indicated the 
product category. Brands located in the game did not exist in the real world and were created for research purposes. It was aimed at eliminating the impact of the player's previous experience with the brand. Each brand appeared 10 times during the game played by each participant. In addition, the visibility of the product and the degree of game - product congruence were manipulated in the game. The brands were placed in central places of the game, for example on gates that a racing car had to cross and in less visible places, such as billboards in the background. After playing the game, participants were asked to answer questions assessing their level of previous experiences as players as well as recognizing and remembering brand names. Demographic information was also collected and control variables were measured. The results confirmed that the location of the brand in the game is important for the effectiveness of the promotion. Products embedded in a more visible way were remembered much better by the players than those placed in the background. The less experienced a player was, the difference was greater (he played less computer games in the past). It was also confirmed that the congruence between the game and the product also influences the reception of the promotional message. Very incongruent products with the game were better remembered. Lee and Faber pointed out that the brand recall is not the only goal of product placement. While the player better remembers the incongruent brands, it can arouse negative attitude towards the brand (Lee \& Faber, 2007).

According to Rozendaal et al. (2013), the most important factor determining the effectiveness of product placement in computer games is persuasive knowledge of players. Persuasion knowledge is defined as a consumer's imagination about motives of promotional message, strategies and tactics. The authors listed four following components of persuasive knowledge: recognition of advertising, understanding of a commercial source of message, understanding of intentions, and a critical attitude towards the message (Rozendaal et al., 2013). Vast parts of the article related to children' persuasive knowledge, as they are an attractive target market. It aroused a great deal of controversy (Büttner, Florack \& Serfas, 2014). According to some studies, children before the age of five cannot distinguish advertising from a television program. They begin to see the real purpose of advertising around the age of eight and accurate perception of intentions is obvious to them at the age of twelve. A large majority of studies show that the recognition and understanding of forms of promotion such as product placement in films and computer games matures much later than in the case of television advertising (Rozendaal et al., 2013). According to the Persuasion Knowledge Model presented by Friest and Wright, knowledge about sellers, intentions and tactics is developed with age (An \& Stern, 2011). Children who understand only the informational intention of advertising are more likely to accept the promotional content without questioning its ulterior motives. On the other hand, recognition of sales intentions can change the child's response to a promotional message and limit their confidence (An \& Stern, 2011).

In order to crate effective product placement through computer games, it is essential to consider the different methods of product or brand integration. Product placement needs to be successfully incorporated into the virtual environment. Three levels of integration of the product in games can be distinguished, namely associative, illustrative and a demonstrative level.

Associative is the lowest level of integration, in which the product or brand is linked to a certain lifestyle or a particular activity featured in the game. The most common form of associative level is displaying the brand identifier or company's product in the background. For instance, Jack Daniel's logotype placed on the pool table in a billiard game or banner ads of breweries embedded around the stadium in a soccer game. In many countries drinking beer and watching a soccer game is closely related. This type of integration is most valuable when the brand image is enhanced by the content or theme of the game.

The second level of brand incorporation, illustrative, takes place when the product plays a significant role in the game, such as Lego's use of Lego characters in its online games.

Demonstrative is the highest level of brand incorporation. In this type of product placement, game suppliers allow the player to experience with the product. The product is a natural part of the game environment. Players can interact with the features of the product. An example is the Nike game, when the player can select a shoe model for a virtual character. Another great example is represented by a digital racing game in which players have the opportunity to select a car model for the races.

Associative and illustrative product incorporation are inexpensive alternatives utilized to get attention to a particular product and are aimed to enhance brand awareness in existing and potential customers. The demonstrative incorporation often requires a sophisticated and customized game concept. On the 
one hand this solution is more expensive to develop and maintain, but on the other hand makes the customer more involved with the product and arouse a deeper impression.

Winkler and Buckner (2006) investigated the level of brand or product recall after playing a certain game. They used three online games, each of which incorporates a different one of the product integration strategies. Game 1 was a sports game featuring the BMW X3 car. During the game players drove the BMW through a hilly countryside. This represented a demonstrative approach. Game 2 was a golf game sponsored by Nabisco. In this game different kinds of Nabisco cookies and crackers were embedded in an illustrative way. Game 3 was a strategy game that promoted M\&M's chocolates candies. The goal of the game was to get three candies of the same color. This game was related to an associative approach. Respondents played the games and next filled in an online questionnaire. Respondents were asked to enter the name of the company, brand, and what kind of product was supported in the game, if they could remember. During one month, 42 questionnaires were collected.

In general, the level of recall was high. Amongst all respondents only six players (14\%) did not recall any of the three categories. Three of these individuals had played Game 1 (game with BMW X3 placement) and the other three played Game 2 (Nabisco cookies and crackers). All users that had played Game 3 (M\&M's chocolates) had remembered at least one of the three categories. The results suggest that very simple games, such as the M\&M's represented in Game 3, are the most effective due to the fact that a more complicated game plot or games where tasks are more demanding players can miss the promotional messages (Winkler \& Buckner, 2006).

\section{Conclusion}

Recently, we have witnessed the evolution of product placement in computer games. This new medium attracted many well-known companies like IBM, Adidas, Toyota or Coca-Cola. They embedded the products or brands in the game plot in similar ways as in television program or films. The growing ranks of scholars has been observed to have an interest in the effectiveness of this new promotional tool. Based on literature review, it can be said that an effectiveness of product or brand placement in a game environment is determined by:

- degree of product/brand visibility in the game (prominence as well as proximity),

- game-product congruity,

- customer engagement in a game,

- persuasive knowledge,

- strategy of product or brand integration with the game.

Despite the progress made, there are still important limitations of conducted research. For example, research results can be moderate by various circumstances such as the use of fictitious or real brands. In addition, the same factor can have positive as well as negative effect. For instance, product placement proximity on the one hand enhances brand recall, but on the other can cause a negative attitude toward the brand. There are also determinants with limited research, including the influence of product or brand integration with the game on product (or brand) effectiveness.

\section{References:}

An S., Stern S. (2011) Mitigating the effects of advergames on children, Journal of Advertising, 40(1), 43-56.

Arakji, R., \& Lang, K. (2008). Avatar business value analysis: a method for the evaluation of business value creation in virtual commerce.

Büttner O. B., Florack A., Serfas B. G. (2014). A dual-step and dual-process model of advertising effects: Implications for reducing the negative impact of advertising on children's consumption behavior, Journal of Consumer Policy, 37(2), 161-182.

Cauberghe V., De Pelsmacker P. (2010), Advergames. The impact of brand prominence and game repetition on brand responses, "Journal of advertising", t. 39, nr 1, ss. 5-18.

Gangadharbatla, H., Bradley, S., \& Wise, W. (2013). Psychophysiological responses to background brand placements in video games. Journal of Advertising, 42(2-3), 251-263.

Gupta, P. B., \& Lord, K. R. (1998). Product placement in movies: The effect of prominence and mode on audience recall. Journal of Current Issues \& Research in Advertising, 20(1), 47-59.

Hofman-Kohlmeyer, M. (2017). The role of product placement in brand management on example of Second Life game. Zarządzanie społeczno-ekonomiczne wobec wyzwań XXI wieku, 165-169.

Kaplan A. M., Haenlein M. (2009a). Consumer use and business potential of virtual worlds: the case of "Second Life". The International Journal on Media Management, 11(3-4), 93-101. 
Kaplan, A. M., \& Haenlein, M. (2009b). The fairyland of Second Life: Virtual social worlds and how to use them. Business horizons, 52(6), 563-572.

Koles, B., \& Nagy, P. (2012). Virtual customers behind avatars: The relationship between virtual identity and virtual consumption in second life. Journal of theoretical and applied electronic commerce research, 7(2), 87-105.

Kotler P., Marketing, Wydawnictwo Rebis, Poznań 2005.

Laskowska-Witek, J., \& Mitręga, M. (2014). Brand Promotion Throught Computer Games on the Example of Second Life. Studia Ekonomiczne, 205, 34-48.

Lee M., Faber R.J. (2007), Effects of product placement in on-line games on brand memory: A perspective of the limitedcapacity model of attention, "Journal of advertising", t. 36, nr 4, ss. 75-90.

Mackay, T., Ewing, M., Newton, F., \& Windisch, L. (2009). The effect of product placement in computer games on brand attitude and recall. International Journal of Advertising, 28(3), 423-438.

Martí-Parreño, J., Aldás-Manzano, J., Currás-Pérez, R., \& Sánchez-García, I. (2013). Factors contributing brand attitude in advergames: Entertainment and irritation. Journal of Brand Management, 20(5), 374-388.

Mitręga, M. (2012). Reklama w grach komputerowych-wstepne badanie postaw graczy w Polsce. Marketing $i$ Rynek, (6), 3036.

Mitręga, M. (2013). Advergaming jako rozwijająca się forma komunikacji marketingowej. Studia Ekonomiczne, (140), 133143.

Mitręga, M., \& Hofman-Kohlmeyer, M. (2017). Komunikacja marketingowa w grach komputerowych-przyrost wiedzy, kierunki badań. MARKETING I RYNEK 12/2017, p. 83

Rozendaal, E., Slot, N., Reijmersdal, E. A., Buijzen, M. (2013). Children's Responses to Advertising in Social Gamesp. Journal of Advertising, 42(2-3), 142-154.

endra Sharma, G., Baoku, L., \& Lijuan, W. (2012). Online marketing in second life virtual world. Asian Journal of Marketing, $6(1), 10-15$

Śliwińska K., Pacut M. (2011), Narzędzia i techniki komunikacji marketingowej XXI wieku, Oficyna a Wolters Kluwer business, Warszawa.

Vashisht, D., Vashisht, D., Pillai, S. S., \& Pillai, S. S. (2016). Are they really persuaded with the brand embedded in the game? Analyzing the effects of nature of game, brand prominence and game-product congruence. Journal of Research in Interactive Marketing, 10(3), 249-264.

Winkler, T., \& Buckner, K. (2006). Receptiveness of gamers to embedded brand messages in advergames: Attitudes towards product placement. Journal of Interactive Advertising, 7(1), 3-32. 